\title{
Long-Term Effects of Enriched Environment on Neurofunctional Outcome and CNS Lesion Volume After Traumatic Brain Injury in Rats
}

\author{
M. MAEGELE ${ }^{1,2}$, M. BRAUN ${ }^{1}$, A. WAFAISADE ${ }^{1,2}$, N. SCHÄFER ${ }^{1}$, \\ M. LIPPERT-GRUENER ${ }^{3}$, C. KREIPKE $^{4}$, J. RAFOLS $^{4}$, U. SCHÄFER ${ }^{5}$, \\ D. N. ANGELOV ${ }^{6}$, E. K. STUERMER ${ }^{1}$
}

${ }^{1}$ Institute for Research in Operative Medicine (IFOM), University of Witten-Herdecke (Campus Cologne-Merheim), Cologne, Germany, ${ }^{2}$ Department for Traumatology and Orthopedic Surgery, Cologne-Merheim Medical Center (CMMC), University Witten-Herdecke (Campus CologneMerheim), Cologne, Germany, ${ }^{3}$ Department for Neurosurgery, University of Cologne Medical Center, Cologne, Germany, ${ }^{4}$ Department of Anatomy, Wayne State University School of Medicine, Detroit, Michigan, USA, ${ }^{5}$ Experimental Neurotraumatology, University Hospital for Neurosurgery, Medical University Graz, Graz, Austria, ${ }^{6}$ Institute for Anatomy, University of Cologne, Cologne, Germany

Received September 23, 2013

Accepted May 30, 2014

On-line September 5, 2014

\section{Summary}

To determine whether the exposure to long term enriched environment (EE) would result in a continuous improvement of neurological recovery and ameliorate the loss of brain tissue after traumatic brain injury (TBI) vs. standard housing (SH). Male Sprague-Dawley rats (300-350 $\mathrm{g}, \mathrm{n}=28$ ) underwent lateral fluid percussion brain injury or SHAM operation. One TBI group was held under complex EE for 90 days, the other under $\mathrm{SH}$. Neuromotor and sensorimotor dysfunction and recovery were assessed after injury and at days 7, 15, and 90 via Composite Neuroscore (NS), RotaRod test, and Barnes Circular Maze (BCM). Cortical tissue loss was assessed using serial brain sections. After day $7 \mathrm{EE}$ animals showed similar latencies and errors as SHAM in the BCM. SH animals performed notably worse with differences still significant on day 90 ( $p<0.001)$. RotaRod test and NS revealed superior results for $\mathrm{EE}$ animals after day 7 . The mean cortical volume was significantly higher in $\mathrm{EE}$ vs. $\mathrm{SH}$ animals $(p=0.003)$. In summary, EE animals after lateral fluid percussion (LFP) brain injury performed significantly better than $\mathrm{SH}$ animals after 90 days of recovery. The window of opportunity may be wide and also lends further credibility to the importance of long term interventions in patients suffering from TBI.

\section{Key words}

Traumatic brain injury - Enriched environment - Controlled cortical impact • Neurobehavioral • Functional recovery

\section{Corresponding author}

M. Maegele, Department of Traumalogy and Orthopedic Surgery, University of Witten/Herdecke, Cologne-Merheim Medical Center (CMMC), Institute for Research in Operative Medicine (IFOM), Ostmerheimerstr. 200, D-51109 Cologne, Germany. Fax: +49 221989 5721. E-mail: Marc.Maegele@t-online.de

\section{Introduction}

Traumatic brain injury (TBI) continues to be the leading cause of death and long-term disability worldwide (Waxweiler and Thurman 1995, Bruns and Hauser 2003, Langlois and Rutland-Brown 2006). In the United States an estimated number of 1.6 million persons sustain a TBI each year with 52,000 deaths and 80,000 patients suffering from permanent neurological impairment (Sosin et al. 1991, Bruns and Hauser 2003). Only 1/4 patients of the total may reach good recovery with no or only 
minimal deficits. Thus, TBI represents a highly relevant medical and socioeconomic burden for modern societies (Murray and Lopez 1997, Ghajar 2000).

The main features of the central nervous system (CNS) response to traumatic brain injury (TBI) have been principally elucidated. Using the lateral fluid percussion (LFP) model in rats (McIntosh and Vink 1989, Dietrich et al. 1996, Pierce and Trojanowski 1996), numerous investigations describe the major histopathological consequences to trauma: lesion-induced vascular perturbations (Cortez and McIntosh 1989, Schmidt and Grady 1993, Fukida et al. 1995), glial hypertrophy and proliferation (Hill and Barbarese 1996), and neuronal necrosis (Soares et al. 1992, 1995, Dietrich et al. 1994a,b, Hicks and Soares 1996, McIntosh and Vink 1989). These reports also confirm that, causing profound cell death (necrotic and apoptotic) and axonal degeneration throughout the brain (Cortez and McIntosh 1989, Dietrich et al. 1994a, Soares et al. 1995, Hicks and Soares 1996, Conti et al. 1998), the LFP model is the one that most closely mirrors postlesional events associated with TBI in humans (McIntosh and Vink 1989, Dietrich et al. 1996, Pierce and Trojanowski 1996, Graham et al. 2000).

Voluminous experimental work has been conducted to characterize new neurobiological events after TBI (Saatman et al. 2001, Stein et al. 2002), unknown effect(s) of different pharmacological trials (Wahl et al. 2000, Belayev et al. 2001, Bentzer et al. 2001, Faden et al. 2001, 2003, LaPlaca et al. 2001, Marklund et al. 2001, Alessandri et al. 2002), and various post-traumatic treatments (Dietrich et al. 1994a, Bramlett and Dietrich 1997, Philips et al. 2001, Knoblach and Faden 2002, Hicks and Zhang 2002, Rice et al. 2002). Only some studies have focused on the concept of environmental enrichment (EE) after TBI, first described by Hepp et al. (1947), and then further developed by Diamond and Krech (1964), Rosenzweig (1966) and Dobbing (1970). To date, a series of behavioral, cellular, and molecular studies have revealed significant effects of EE on rodents and other species, and provided new insights into the mechanisms of experienced-dependent plasticity, including adult neurogenesis and synaptic plasticity (Nithianantharajah and Hannan 2006). EE has been reported to lead to enhanced expression of trophic factors and neurogenesis and to increase the number of dendrites, synapses, glia cells and blood vessels (Falkenberg and Mohammed 1992, Kempermann and Kuhn 1997, Nilsson and Perfilieva 1999). At the behavioral level, EE enhances learning and memory (Myslivecek and Hassmannova 1987, Moser et al. 1997, Rampon et al. 2000a,b, Tang et al. 2001, Schrijver et al. 2002, Lee et al. 2003), reduces memory decline (Bennett et al. 2006), decreases anxiety, and increases exploratory activity (Chapillon et al. 1999, Roy et al. 2001, Benaroya-Milshtein 2004, Friske and Gammie 2005).

To date, the maximum observation periods after TBI and exposure to EE have been restricted to four to eight weeks following impact only. Thus, the regeneration potential of the experimentally lesioned brain beyond this time window including ways to trigger these potentials for improved outcome is still scarce. Further, it is not known whether there exist specific time windows within the post-injury sequalae beyond traditional survival times in which the lesioned brain is more receptive for external clues that may be translated into central reorganization and improved function. In considering a standardized experimental approach and the key aspects of EE, i.e. environmental complexity and novelty (Nithianantharajah and Hannan 2006), the present research proposal aimed to further investigate the benefits associated with EE, that have been observed up to 30 days post-injury (Maegele and Lippert-Gruener 2005a,b, Lippert-Gruener et al. 2006a,b), but now on an extended time scale up to three months after injury. Together with previous findings results may be translated into optimizing current clinical stimulation concepts in the rehabilitation of brain trauma patients (LippertGruener and Terhaag 2000, Lippert-Gruener et al. 2002, 2003).

\section{Materials and Methods}

\section{Overview of experimental animal groups}

Male Sprague-Dawley rats $(300-350 \mathrm{~g}, \mathrm{n}=28)$

were obtained from Harlan-Winkelmann (Borchen, Germany) and housed in individual cages. After acclimatization, animals were randomized into the two housing paradigms: in standard housing $(\mathrm{SH})$ or in an EE for a total of 90 days after surgery. Each group consisted of 14 animals, 4 sham-operated animals as well as 10 traumatized animals. For analysis SHAM animals from both housing paradigms were pooled into one group $(n=8)$ a priory as we assumed no significant effect of housing paradigm on our outcome parameters. Furthermore, this group size increased the statistical power. All experimental procedures confirmed with the guidelines of the Witten-Herdecke University and the 
Local Animal Ethics Committee.

Operative procedures and lateral fluid percussion brain injury (LFP)

The LFP brain injury model is one of the most widely used and well characterized models of experimental traumatic brain injury (Laurer and Lenzlinger 2000) and has been described previously (McIntosh and Vink 1989). In brief, under anesthesia with sodium pentobarbital $(60 \mathrm{mg} / \mathrm{kg}$ BW i.p.), animals were fixated in a stereotaxic frame (Kopf Instruments, Tujunga, CA, USA). After incision of the scalp, the temporal muscles were reflected and a $4.8 \mathrm{~mm}$ craniotomy, $2.5 \mathrm{~mm}$ lateral to the sagital sinus and centered between bregma and lambda was drilled, keeping the dura mater intact. To this a hollow female Luer-Lok fitting was fixated using dental cement. TBI was induced with the fluid percussion device. Prior to induction of trauma a connection between the female Luer-Lok, anchored in the rats skull and the male one on the fluid percussion device was made, creating a closed system filled with isotonic saline in connection with the dura. For the induction of trauma, a metal pendulum was released from a pre-selected height, striking the other end of the Plexiglas piston. The induced rapid injection of saline into the closed cranial cavity thus created a pulse of increased intracranial pressure of 21-23 ms duration. This caused a brief displacement and deformation of neural tissue. The pressure pulse was recorded using a computer oscilloscope emulation program (RC Electronics, Santa Barbara, CA, USA) via a transducer (Gould) housed in the injury device. The injury was induced at a moderate level (2.1 atm). Afterwards the cemented Luer-Lok was removed from the scull, the incision closed by interrupted 4.0 silk sutures and the animals placed onto a heated pad for $1 \mathrm{~h}$ following surgery. Sham operated animals underwent surgical procedures as described above without being subject to LFP brain injury.

\section{Standard housing and enriched environment}

After surgery rats held in the standard housing paradigm remained in standard cages $(425 \times 266 \times$ $185 \mathrm{~mm}$; polycarbonate, Techniplast, Buguggiate, Italy) with no specific stimulation. Rats subjected to EE were placed in specifically designed cages, experiencing group living. The EE consisted of three cages, $610 \times 435 \times$ $215 \mathrm{~mm}$ of size, connected in a row via tunnels. The EE furthermore consisted of horizontal and inclining platforms, climbing ladders, balls, tunnels, bridges, hanging ropes, bells. Objects and toys were randomly circulated as some were removed and others were added within the course of the experiment. In both housing paradigms food and water were available ad libitum; temperature was $22{ }^{\circ} \mathrm{C}$ and a $12 \mathrm{~h}$ light-dark-cycle. The sham operated animals were randomized into one of either housing paradigms. Wherever scientifically feasible their results were pooled to reduce the total number of animals used. All trials were performed by an investigator blinded to housing paradigm and injury status.

\section{Neurofunctional evaluation (Composite Neuroscore)}

Evaluation of neuromotor impairment after TBI by using a Composite Neuroscore (NS) test has been described previously (Okiyama et al. 1992, Sinson et al. 1995) and results correlate with injury severity (Sullivan et al. 1976, McIntosh and Vink 1989). Scoring for each animal ranged from 0 (severely impaired) to 4 (normal strength and function) for each of the following modalities: (1) left and (2) right forelimb flexion during suspension by the tail; (3) left and (4) right hind limb flexion with the forelimbs remaining on a flat surface as the hind limbs are lifted up and down by the tail; (5) ability to resist lateral pulsion to the left and (6) right; (7) ability to stand on an inclined plane in the left; (8) right and (9) vertical position. Inclined plane scoring (0-4) is determined by the animal's ability to stand at an angle up to 45 degrees $\left(4=45^{\circ}, 3=42.5^{\circ}, 2=40^{\circ}, 1=37.5^{\circ}, 0 \leq 37.5^{\circ}\right.$ ). The scores for (7), (8), and (9) were averaged, and a composite neurological motor score (0-28) was calculated for each animal from the summation of individual test scores. Baseline composite neuromotor scores were calculated $24 \mathrm{~h}$ prior to injury. The degree of acute neurological impairment after trauma and prior to the beginning of either $\mathrm{SH}$ or EE was assessed in all animals at $24 \mathrm{~h}$ post-injury; the recovery of neuromotor functions was evaluated blinded to the injury status at days post-injury 7,15 , and 90 days.

\section{Sensorimotor coordination (Rota-Rod test)}

Sensorimotor coordination was assessed using the Rota-Rod test (IITC Life Science, Woodland Hills, USA) (Dunham and Miya 1957, Jones and Roberts 1968). For the test a series of three trials with at least 5 min of rest was performed. All animals were placed on a cylinder which then gradually began to rotate with an increasing speed of 0 to $30 \mathrm{rpm}$ within $60 \mathrm{~s}$. The animals 
were placed on textured drums to avoid slipping. The system provided individual timers for measuring the time the animals stayed on the rod. Animal falls were detected by light-beam sensors mounted into each compartment. Each trial was terminated if an animal fell or jumped of the cylinder or remained on it for $>90 \mathrm{~s}$. The mean duration (in s), distance (in m), and maximum speed (in rpm) were recorded for a series of three consecutive trials. Animals were allowed to recover in their home cages for at least $3 \mathrm{~min}$ before a new trial was started. Baseline values were recorded $24 \mathrm{~h}$ prior to injury. The extent of sensorimotor impairment was surveyed at $24 \mathrm{~h}$ post-injury and at days post injury 7, 15, and 90 after trauma the extent of recovery was assessed.

\section{Spatial reference memory (Barnes Circular Maze)}

The Barnes Circular Maze (Barnes 1979) has been adapted to assess spatial reference memory following TBI (Maegele et al. 2005). The maze represents an efficient and proven alternative to the commonly used water-maze-test with less stress to the animal, less physical demand, and fewer trials over fewer days for satisfactory training (Fox et al. 1998). During the Barnes Circular Maze procedure, the animals had to locate a dark escape chamber, hidden underneath one of a series of holes around the perimeter of a bright disc. This disc was illuminated by four overhead lamps to create a low-level adverse stimulus. Our maze was manufactured from white acrylic plastic to form a disk $1.5 \mathrm{~cm}$ thick and $122 \mathrm{~cm}$ in diameter, with 18 evenly spaced holes, $7 \mathrm{~cm}$ in diameter, at its periphery. All trials were recorded by a video camera above the maze to measure the distance covered by each animal using an electronic tracking system. Animals had to perform two trials per day for five consecutive days (day 85-89 after TBI). Trials were ended after the animal had entered the escape chamber or when a pre-determined time $(300 \mathrm{~s})$ had elapsed, whichever occurred first. All surfaces were cleaned before each trial to eliminate possible olfactory cues from preceding animals.

Forelimb sensorimotor function (Limb-use asymetry test, Cylinder test)

Experimental LFP brain injury is known to be associated with reduced contralateral forelimb motor function and coordination (McIntosh and Vink 1989, Pierce and Smith 1998, Schallert and Fleming 2000, DeBow et al. 2003, Grow and Liu 2003). When placed in the cylinder, animals will usually rear and explore the cylinder walls with their forepaws, allowing three categories of placements to be recorded: i) independent ipsilateral limb use, ii) independent contralateral limb use, and iii) both movements, when the animal uses both paws in unison or in quick succession. Symmetry of forelimb use was assessed by videotaping rats for $3 \mathrm{~min}$ while exploring a transparent glass cylinder $(25 \mathrm{~cm}$ in diameter, $30 \mathrm{~cm}$ in height). To facilitate scoring of movements while the animal was facing away from the camera, a mirror was placed behind the cylinder. Animals were tested using a red lamp in the dark during the animals' light phase, to encourage exploratory behavior and rearing. Scoring of forelimb use was done blinded to housing and surgery status. The scored behaviors were calculated in percentage use of the forelimb used (ipsilateral, contralateral, and both) in relation to the total number of limb use observed. Values were recorded $24 \mathrm{~h}$ prior and $24 \mathrm{~h}$ post-injury. Recovery was evaluated at days 7,15 , and 90 post injury.

\section{Tissue preparation}

At day 90 post-injury, the animals were re-anesthetized and transcardially perfused with $0.9 \%$ $\mathrm{NaCl}$ in distilled water for $60 \mathrm{~s}$ followed by fixation with $4 \%$ paraformaldehyde (PFA) in $0.1 \mathrm{~m}$ phosphate buffer ( $\mathrm{pH}$ 7.4). After removal, brains were stored in $4 \% \mathrm{PFA}$ until further processing. For quantification of lesion volume four animals from each group were selected at random. Brains for immunocytochemistry were placed in a cryoprotective solution for $24 \mathrm{~h}(20 \%$ sucrose in $4 \%$ PFA). Brains were then precut using a brain slicer matrix (Zivic Instruments, Pittsburgh, PA, USA). The rostral border of the resection was defined by the demarcation of the infundibular recess (Bregma $-0.3 \mathrm{~mm}$ ) the caudal cut was made approximately $8 \mathrm{~mm}$ dorsally (Bregma $-6.8 \mathrm{~mm}$ ). The resulting brain-slice was embedded in TFM $^{\mathrm{TM}}$ tissue freezing medium (Triangle Biomedical Sciences, Inc., Durham, NC, USA). After freezing at $-80{ }^{\circ} \mathrm{C}, 40 \mu \mathrm{m}$-thick sections were cut on a Cryostat and stored in 1x PBS (P5493, Sigma-Aldrich CO, St. Louis, MO, USA) until further processing.

\section{Immunocytochemistry}

Immunocytochemistry was performed on $40 \mu \mathrm{m}$-thick, free-floating sections. After sections were washed in $1 \times$ PBS quenching of endogenous peroxidase was performed using $500 \mu \mathrm{l}$ per section of $3 \% \mathrm{H}_{2} \mathrm{O}_{2}$ in water (Sigma-Aldrich CO, St. Louis, MO, USA) for 5 min, followed by thorough washing in 1xPBS. Sections 
were then incubated in $500 \mu 10.6 \%$ Triton-X 100 in 1xPBS (Sigma-Aldrich CO, St. Louis, MO, USA) containing $5 \%$ NGS (Normal Goat Serum, SigmaAldrich CO, St. Louis, MO, USA) and primary antibody, GFAP (1:150, G3893, Sigma-Aldrich CO, St. Louis, MO, USA). Sections were placed on a rocker (Shaker 25, Labnet International Inc., Woodbridge, NJ, USA) for $24 \mathrm{~h}$. After 3 washes in $1 \times$ PBS, sections were processed using the Vectastain Elite Kit (Vector Laboratories, Inc., Burlingame, CA, USA). Biotinylated secondary antibody was used at 1:200 in 1xPBS, A and B reagents were used at 1:66 each. The incubation time was $30 \mathrm{~min}$ each. Visualization was performed with 3.3'-DAB (Sigmafast $^{\mathrm{TM}}$, D4293, Sigma-Aldrich CO, St. Louis, MO, USA). For controls, sections incubated with the omission of primary antibody yielded blank sections. Sections were then mounted on Fisherbrand ${ }^{\mathrm{TM}}$ slides (Fisher Scientific, Pittsburgh, PA, USA), air-dried, cleaned in Xylenes and coverslipped using Permount ${ }^{\circledR} \quad$ (Fisher Scientific, Pittsburgh, PA, USA).

\section{Quantification of cortical tissue loss}

The assessment of differences in tissue loss between both groups was performed by measuring cortical thickness from Bregma -1.3 to Bregma -6.3. As previously demonstrated, regions with greatest cortical damage are located in between those two planes at time points between one month and one year after LFP induced TBI (Cortez and McIntosh 1989, Hicks and Soares 1996, Smith and Chen 1997). In accordance to the fractionators sampling strategy we stained every $20^{\text {th }}$ coronal section throughout the pre-cut brain (a total of 6 equidistant sections) using GFAP-staining. The cortical volume for each group was calculated according to the Cavalieri method (Gundersen et al. 1988), multiplying the total lesioned area $\left(\mu \mathrm{m}^{2}\right)$ by the mean section thickness $(40 \mu \mathrm{m})$. Detailed accounts of the principles and the procedures for calculating coefficients of error are given in Gundersen and Jensen (1987) and West and Gundersen (1990). In brief, the cortical volume $(V)$ was estimated using an exhaustive set of parallel slices through the brain at a known mean slice separation $(d)$. The position of the first slice must be uniform random in the interval $0-d$. It is important that only one face of each section is measured. The slice areas of the appropriate faces were estimated by randomly superimposing a systematic array of test points on each face in turn. The points falling on all of the section faces, $\mathrm{P}$ were counted. The estimated object volume could be calculated by the formula: $V=\mathrm{A} d=\mathrm{P} a(p) d$. In this calculation $a(p)$ is the areal equivalent of one test point on the scale of the specimen (=brain). Previously, it was shown that efficient estimates could be obtained from few as five to six slices per object or brain, respectively (Mayhew 1991). Cortical thickness was measured in $\mu \mathrm{m}$ to estimate the total lesion area in $\mu \mathrm{m}^{2}$. Image acquisition for quantification of cortical thickness was performed using a Nikon D3 with AF-S Micro Nikkor $60 \mathrm{~mm}$ lens (Nikon Europe B.V.). Image calibration and analysis was performed using AxioVision 4.8 software (Carl Zeiss Inc.).

\section{Statistical analysis}

All statistical analysis was performed using SPSS 13.0 software. Data surveyed from all experimental groups was tested for differences using one-way descriptive statistics and one-way ANOVA as well as post-hoc analysis. A level of significance of $\mathrm{p}<0.05$ was used for all analyses.

\section{Results}

Neurofunctional evaluation (Composite Neuroscore)

In the Composite Neuroscores (NS) no differences were observed between intact animals pre-injury with respect to forelimb flexion, lateral pulsation, hind limb function and baseline angles in the angle-board test. At $24 \mathrm{~h}$ post-injury, all animals subjected to LFP brain injury showed a similar level of severe neurofunctional impairment compared to their uninjured SHAM counterparts irrespective of housing conditions (SHAM: $28 \pm 0.0, \mathrm{SH}: 12.2 \pm 1.0$, EE: 11.7 \pm 1.1 , both $\mathrm{p}<0.005$ vs. SHAM ). Within the first week after injury, EE animals recovered significantly some neurological function (EE 15.2 \pm 1.4 ) while animals held under standard housing displayed a worsening with respect to their neurofunction (SH 10.2 \pm 0.9 ) (Fig. 1). Within the further sequalae of the experiment until the end of the observation period (day 90) both groups (SH and EE groups) recovered a considerable amount of neurofunction but with EE animals being always significantly superior $(\mathrm{p}<0.005)$ over $\mathrm{SH}$ animals at all time points studied (SH 19.3 \pm 1.1 , EE 22.4 \pm 1.7 ).

\section{Sensorimotor coordination (Rota-Rod Test)}

Within 90 days of the trial SHAM rats showed excellent results in the three categories of the sensomotoric test (dpi-1: $2.49 \pm 1.42 \mathrm{~m}, 23.07 \pm 447 \mathrm{rpm}$, $49.02 \pm 14.9 \mathrm{~s}, \quad \mathrm{dpi}+90: \quad 3.04 \pm 1.5 \mathrm{~m}, \quad 26.74 \pm 4.99 \mathrm{rpm}$, 


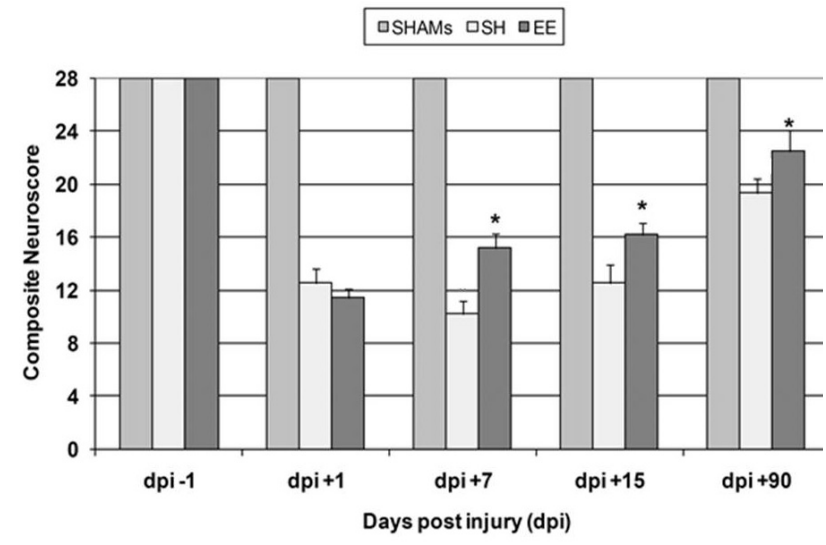

Fig. 1. Composite Neuroscore. Evaluation of neuromotor function and recovery over a 90 day period. All injured animals showed a comparable decline in neuromotor function $24 \mathrm{~h}$ post injury with faster recovery after EE. dpi, days post injury; $\mathrm{SH}$, standard housing; $E E$, enriched environment. Values are shown as mean scores \pm SD. $* p<0.05$ vs. SH.

$55.80 \pm 15.51 \mathrm{~s})$. In the Rota-Rod test at $24 \mathrm{~h}$ post-injury, all animals subjected to LFP brain injury showed a significant decline in all three dimensions of the test, i.e. time, distance and maximum speed sustained compared to their sham counterparts $(\mathrm{p}<0.005$ vs. SHAM), but the difference between SH and EE animals was not significant, indicating a similar level of inflicted brain injury. The $\mathrm{SH}$ rats always showed the highest neurological deficit (dpi+1: $0.4 \pm 0.32 \mathrm{~m}, 9.05 \pm 3.64 \mathrm{rpm}$, $16.65 \pm 7.51 \mathrm{~s})$. Recovery in $\mathrm{EE}$ animals was more pronounced and statistically significant $(\mathrm{p}=0.04)$ for distance (EE: $1.08 \mathrm{~m}$, SH: $0.59 \mathrm{~m}$ ) and time (EE: $31.54 \pm 7.66 \mathrm{~s}, \mathrm{SH}: 21.61 \pm 8.85 \mathrm{~s}$ ) at day 15 post injury while the amount of recovery in SH animals was not (Fig. 2). Both injured groups showed stagnating sensorimotor coordination in the RotaRod test from day 7 to day 15 and exhibited diminishing performance in all three dimensions at day 90 (EE: $0.71 \pm 0.36 \mathrm{~m}$, $12.82 \pm 3.84 \mathrm{rpm}, \quad 24.46 \pm 7.85 \mathrm{~s}, \quad \mathrm{SH}: \quad 0.66 \pm 0.61 \mathrm{~m}$, $11.81 \pm 5.57 \mathrm{rpm}, \quad 22.36 \pm 11.51 \mathrm{~s})$ compared to days 7 and 15. On day 90 post injury no influence of EE on healthy rats could be detected (SHAM+SH: $2.05 \pm 0.67 \mathrm{~m}$, $25.09 \pm 3.38 \mathrm{rpm}, 50.33 \pm 7.51 \mathrm{~s}$, SHAM+EE: $2.72 \pm 0.82 \mathrm{~m}$, $28.76 \pm 1 \mathrm{rpm}, 52.72 \pm 7.79 \mathrm{~s})$.

\section{Spatial reference memory (Barnes Circular Maze)}

At Barnes Circular Maze (BMC) on day 1 animals in EE had found the escape chamber after $89.8 \pm 86.1 \mathrm{~s}$ while animals in $\mathrm{SH}$ animals after $158.8 \pm 92.0 \mathrm{~s}$. Sham operated animals had located the escape box after $129.3 \pm 113.7 \mathrm{~s}$ of search. Errors made in EE- and SH- animals were comparable (7.4 \pm 5.2 vs.

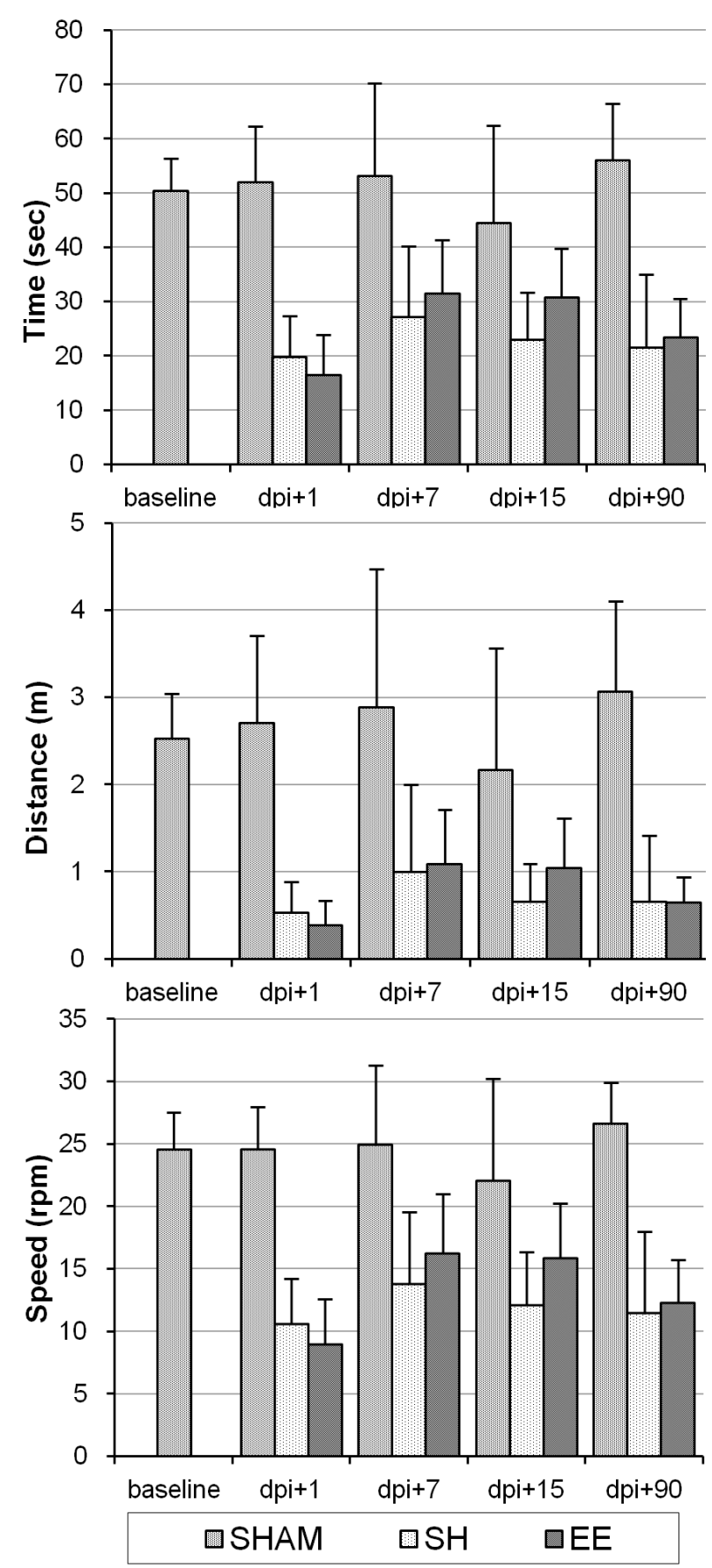

Fig. 2. RotaRod test to evaluate sensorimotor coordination and recovery at baseline, $24 \mathrm{~h}$ post injury (dpi 1 ) and dpi 7, 15, 30 and 90. Injured animals show a similar level of decline (dpi 1) compared to baseline with faster recovery after EE. Values are shown as mean \pm SD for time (seconds), distance traveled (meter) and speed (rounds per minute, rpm). * p <0.05 vs. SH.

7.6 \pm 5.3 ), sham-operated animals made $9.8 \pm 6.1$ errors on average. An apparent learning curve for spatial reference memory was evident in both injured groups as well as in sham-operated animals over the 5 day training period. Animals housed in EE performed better than $\mathrm{SH}$ and 


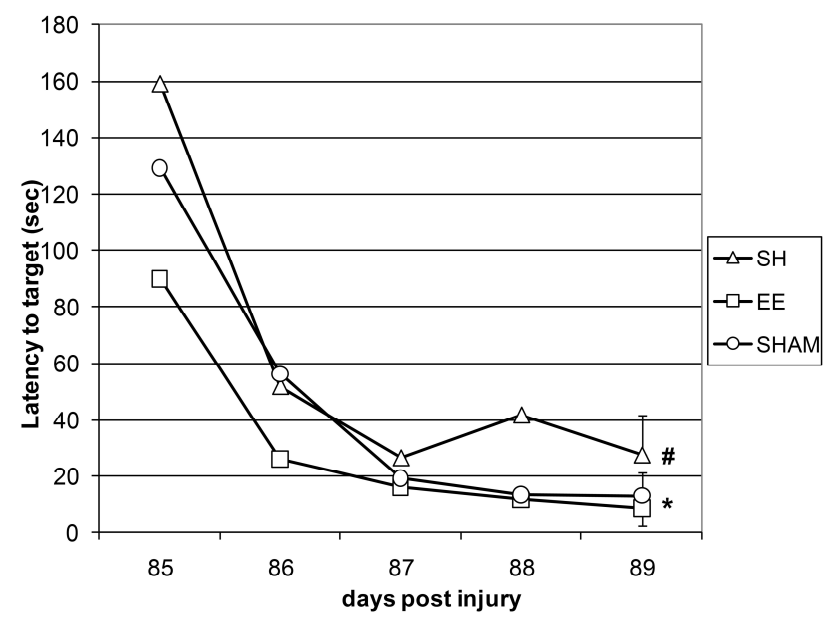

Fig. 3. Spatial reference memory tested with the Barnes Circular Maze at dpi 85-89 (day 1-5) measured by latency to target in sec. EE-stimulated animals performed like sham-operated animals from day 2 . Values are shown as mean scores $\pm \mathrm{SD}$. * $p<0.05$ vs. SH; \# $p<0.05$ vs. SHAM.

sham-operated animals during the duration of the trial with respect to latency. From day 3 onwards, latencies of sham animals were comparable to EE animals (Fig. 3). At BCM day $5 \mathrm{EE}$ animals and sham operated animals showed similar latencies and errors $(8.7 \pm 6.1 \mathrm{~s}$ vs. $13.2 \pm 8.2 \mathrm{~s}$ and $1.9 \pm 2.4$ vs. $2.2 \pm 1.4$ errors). Animals in the SH-group performed notably worse on day 5 of the BCM with respect to latency $(27.5 \pm 14.4 \mathrm{~s})$ and errors $(3.1 \pm 1.8)$. The differences in latencies between the groups on the final $\mathrm{BCM}$ day were statistically significant (EE vs. SH $\mathrm{p}<0.001$ ). On day 90 post injury no influence of $E E$ on healthy rats could be observed (SHAM+EE: $9.33 \pm 5.81 \mathrm{~s}$, $2.25 \pm 2.07$ errors; SHAM+SH: $11.1 \pm 2.68 \mathrm{~s}, 2.25 \pm 1.51$ errors).

Forelimb sensorimotor function and recovery (Limb-use asymmetry test, Cylinder Test)

At baseline, all animals showed a simultaneous use of both forelimbs of approximately $45 \%$ (Fig. 4, dpi-1). Seven days after injury, animals under both housing paradigms showed a not significant decrease of contralateral forelimb use and a slight decline in use of both limbs simultaneously (SH: $39.5 \pm 0.24 \%$, EE: $38.0 \pm 28 \%$ ). Over the course of the study SH animals did show a tendency towards recovery at day 15 but declined until day 90 to comparable forelimb sensorimotor function impairment as shown on day 7 post injury (dpi+90: SH: $33.7 \pm 26 \%$, EE: $43.4 \pm 18 \%$ ). Animals in EE showed a more pronounced and also retained recovery

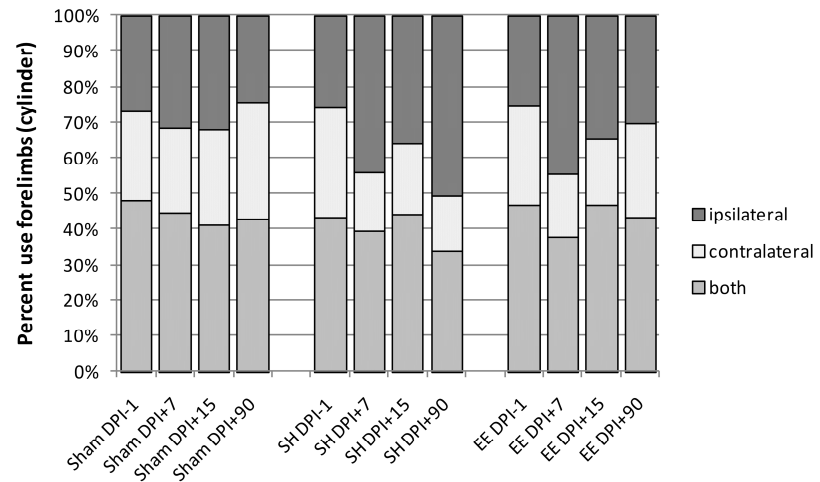

Fig. 4. Assessment of forelimb sensorimotor function during exploration of a glass cylinder before injury (DPI-1), and recovery at day 7,15 and 90 post injury. Percentaged use of forelimb, contralateral forelimb and use of both forelimbs simultaneously were shown with regard to the site of injury with a remarkable decrease of the use of the contralateral limp on 90 DPI in the SH-group; EE-group reached sham-level of the limb at $90 \mathrm{DPI}$. DPI, days post injury; $\mathrm{SH}$, standard housing; $\mathrm{EE}$, enriched environment.

over days 15 to 90 coming close to pre-injury levels. No influence of EE on healthy rats in the simultaneous use of both forelimbs could be detected on day 90 post injury (SHAM+SH: $\quad 48.1 \pm 0.7 \%, \quad$ SHAM+EE: $\quad 49.5 \pm 0.9 \%$ ). None of the group-differences were statistically significant.

Assessment of cortical tissue loss and gross pathological alterations

Animals that were held under SH conditions had a mean cortical volume of $87.5 \pm 5.5 \mathrm{~mm}^{3}$ while animals in EE had a mean cortical volume of $104.1 \pm 4.1 \mathrm{~mm}^{3}$ $(p=0.003$ ) on day 90 post injury (Fig. 5D). Representative sections at Bregma level -3.14 for one animal from each experimental group were shown (Fig. 5A-C). As previously calculated, a markedly reduced loss of cortical thickness was observed for EE animals. Similarly, ventricular enlargement was substantially less pronounced in EE animals compared to $\mathrm{SH}$ animals but was clearly discernible in all injured animals compared to sham-operated animals. We also found that loss of tissue in both internal capsule and hippocampus was more pronounced in $\mathrm{SH}$ animals compared to $\mathrm{EE}$ animals but present in both groups compared to sham operated animals. Astrocytosis throughout the ipsilateral hemisphere was present in all injured animals. It extended from the region of the cortical cavity to the ipsilateral internal capsule, along the commissural fibers and also into the ipsilateral thalamus. 

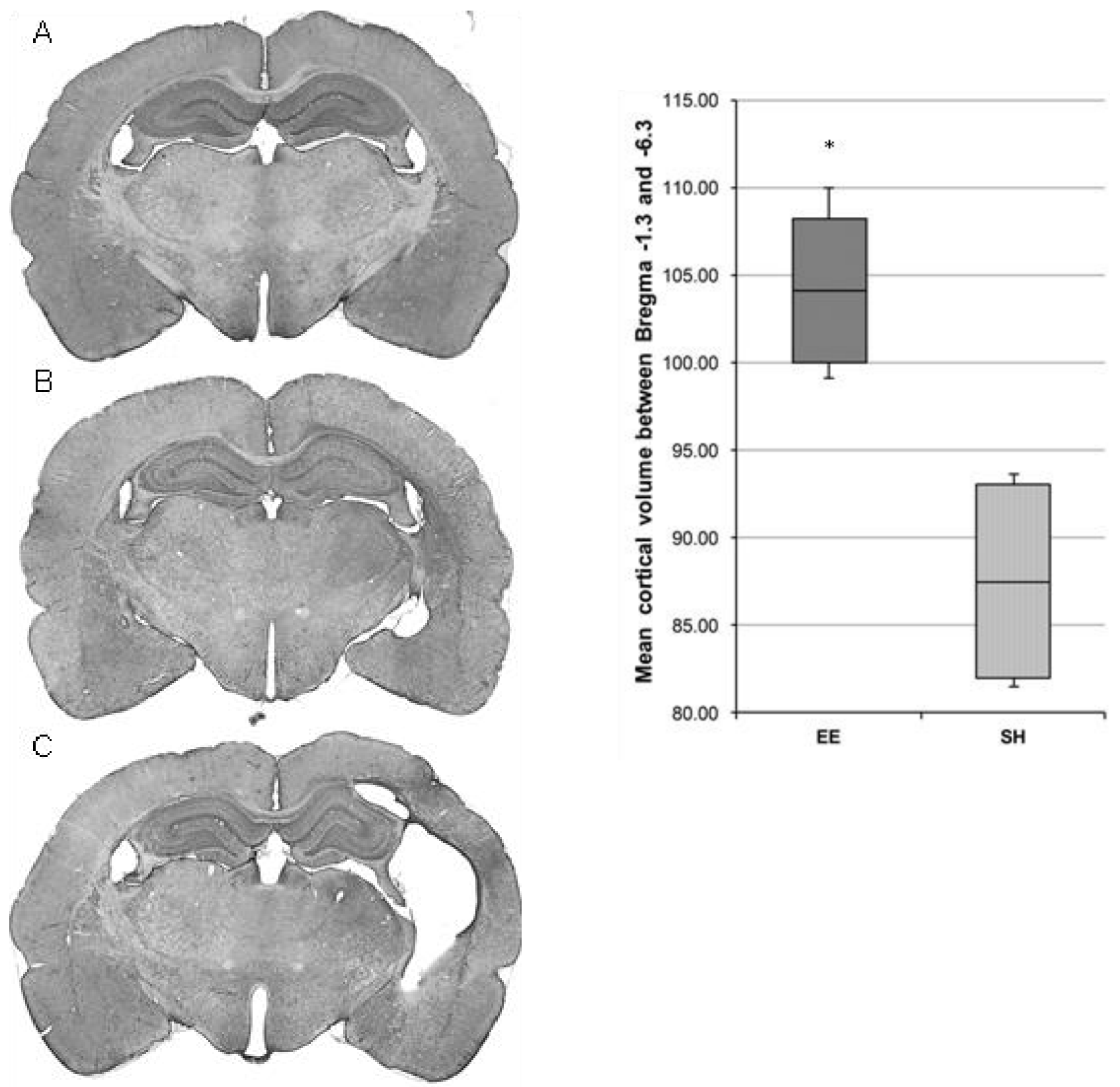

Fig. 5. Rat brain sections at Bregma -3.14 from a representative sham-operated animal (A), a SH (B) and an EE animal (C) after LFP brain injury. Notably difference between SH and EE brains in structural damage of the hippocampus, the external and internal capsule on the injured side. (D) Mean cortical volume after LFP brain injury in $\mathrm{mm}^{3}$ for animals housed in SH and EE ( $\mathrm{n}=4$ per group) calculated according to the Cavalieri method (Gundersen et al. 1988). Boxplots show median \pm SD; whiskers show extrema. $*$ p $<0.05 \mathrm{vs.} \mathrm{SH.}$

\section{Discussion}

Environmental enrichment has been shown to have numerous beneficial effects on brain and behavior. Unfortunately, current knowledge from these investigations is restricted to short-term survival periods (14-30 days) only leaving the potential mid- to long-term benefits associated with EE unclear. Because there is an ongoing loss of brain tissue and impairment of neurological functioning as assessed by the Morris Water Maze and Composite Neuroscore that seem to be progressive for up to one year after LFP brain injury (Smith and Chen 1997, Pierce and Smith 1998) it is of great interest what continuous EE can do. The results for up to 30 days post injury showed promising improvement on functional outcome and tissue integrity following TBI (Maegele et al. 2005). The present study investigating the potential of long-term effects associated with EE after LFP brain injury in rats underlines the findings of Kovesdi et al. (2011) after 71 days of EE and show a decelerated, but continuous recovery of brain function.

In general, animals after subjected to LFP brain 
injury followed by exposure to EE behaved better in three out of four standardized tests to assess both sensorimotor or neuromotor function and spatial reference memory. $\mathrm{SH}$ animals also showed a clear learning-curve but performed worse than injured animals from EE and sham-operated animals. The advantage for EE vs. SH-housed animals with respect to spatial learning as described previously for short-term survival (Hamm and Temple 1996, Maegele et al. 2005) thus seems to be sustained over longer periods post injury as well. The results obtained from the cylinder test for forelimb sensorimotor function and recovery showed also a trend in favor of EE animals however without reaching statistical significance. Histomorphologically, the results from neurofunctional testing were reflected by the preservation of cortical thickness at the lesion site. Although none of the animals in the EE group showed full recovery when compared to baseline and sham-operated animals, the pattern of recovery was similar to that with shorter survival periods as previously reported by our group (Pierce and Smith 1998). Both groups continued to improve their scores markedly from days 30 to 90 post injury.

Voluminous experimental work has been conducted to characterize new neurobiological events after TBI (Saatman et al. 2001, Stein et al. 2002), unknown effect(s) of different pharmacological trials (Wahl et al. 2000, Belayev et al. 2001, Bentzer et al. 2001, LaPlaca et al. 2001, Marklund et al. 2001, Faden et al. 2001, 2003, Alessandri et al. 2002), and various posttraumatic treatments (Dietrich et al. 1994a, Bramlett and Dietrich 1997, Philips et al. 2001, Knoblach and Faden 2002, Hicks and Zhang 2002, Hicks et al. 2002, Rice et al. 2002).

To date, a series of behavioral, cellular and molecular studies have revealed significant effects of EE on rodents and other species, and provided new insights into the mechanisms of experienced-dependent plasticity, including adult neurogenesis and synaptic plasticity. Interestingly, EE seemed to improve the outcome even if it is applied 15 days before TBI (Johnson et al. 2013).

At the behavioral level, EE enhances learning and memory (Moser et al. 1997, Rampon et al. 2000a,b, Tang et al. 2001, Schrijver et al. 2002, Lee et al. 2003), reduces memory decline (Bennett et al. 2006), decreases anxiety, and increases exploratory activity (Chapillon et al. 1999, Roy et al. 2001, Benaroya-Milshtein 2004, Friske and Gammie 2005).

Similarly, several studies have investigated the effects of EE of functional recovery after experimental models of TBI. Meanwhile, there is a body of evidence that that EE following TBI enhances functional outcome and attenuates both motor and cognitive deficits (Schwartz 1964, Will et al. 1976, Whishaw et al. 1984, Kolb and Gibb 1991, Hamm and Temple 1996, van Rijzingen et al. 1997, Passineau and Green 2001, Wagner et al. 2002, Kozlowski et al. 2004), in which early, but not immediate onset seemed to be of advantage (Matter $e t$ al. 2011). A recent study combined EE with a transplantation of murine embryonic stem cells 7 days after brain injury in rats and pointed out a further advantage compared to sole EE stimulation (Peruzzaro et al. 2013).

Early experiments in wild-type rodents investigating the effects of differential housing showed that EE altered cortical weight and thickness (Bennett et al. 1969, Diamond et al. 1972, 1976, van Praag et al. 2000). Enrichment following TBI has been shown to have beneficial effects on the brain, such as preservation of tissue integrity, decreasing lesion size (Passineau and Green 2001), enhancing dendritic branching and the size of synapses (Greenough and Volkmar 1973, Greenough et al. 1973, 1985, Connor et al. 1982, Turner and Greenough 1985, Kolb and Gibb 1991, Rampon et al. 2000a,b, Faherty et al. 2003, Leggio et al. 2005), promoting the survival of progenitor cells (Gaulke et al. 2005), increasing neurotrophins (BDNF, NGF)-that both play integral roles in neuronal signaling (Torasdotter et al. 1998, Pham et al. 1999, Ickes et al. 2000, Chen et al. 2005), and decreasing DAT levels (Wagner et al. 2005). Furthermore, EE has been associated with increased neurogenesis and integration of these newly born cells into functional circuits (Kempermann and Kuhn 1997, Kempermann et al. 1998a,b, 2002, van Praag et al. 2000, Bruel-Jungermann et al. 2005). In both experimental groups, a loss of cortical tissue was observed at 90 days post injury, but EE was comparably associated with a substantial preservation of cortical thickness at the lesion site. Animals in the $\mathrm{SH}$ paradigm did exhibit a markedly more pronounced loss of hippocampal tissue compared to them in EE. Possible explanations for this may be that EE attenuated the acute and delayed tissue damage having neuroprotective properties (Pierce and Trojanowski 1996, Bramlett and Dietrich 1997, Passineau and Green 2001, Hicks and Zhang 2002, Hicks et al. 2002). It enhanced the regenerative plasticity responses of the brain to injury and thus promoted not only functional but also histomorphological recovery (Nilsson and Perfilieva 1999, Passineau and Green 2001). The 
limitation of this study is certainly the qualitative description of ventricular enlargement, astrocytosis and hippocampus tissue loss without quantifying these changes.

\section{Conclusion}

In the present study, animals after LFP brain injury stimulated by EE performed significantly better in three out of four standardized tests to assess sensorimotor and neuromotor function, as well as spatial reference memory after 90 days of recovery. Early observation time points may overestimate the amount of sustained recovery and it may be prudent to include longer survival times into future studies concerning the outcome after treatments of TBI to account for the phenomenon of progressive worsening of neurofunctional and histological outcome parameters over time. Although effective treatments in the acute setting are clearly needed, this study shows that the window of opportunity may be wide and also lends further credibility to the importance of long term interventions in patients suffering from TBI. Continuous cognitive and physical training (physiotherapy, ergotherapy, etc.) on the basis of social integration and supporting medication may to lead to a slow but continuous recovery which is even effective in long-term duration.

\section{Conflict of Interest}

There is no conflict of interest.

\section{References}

ALESSANDRI B, RICE AC, LEVASSEUR J, DEFORD M, HAMM RJ, BULLOCK MR: Cyclosporin A improves brain tissue oxygen consumption and learning/memory performance after lateral fluid percussion injury in rats. J Neurotrauma 19: 829-841, 2002.

ANGELOV D, NEISS WF, GUNKEL A, GUNTINAS-LICHIUS O, STENNERT O: Axotomy induces intranuclear immunolocalization of neuron-specific enolase in facial and hypoglossal neurons of the rat. J Neurocytol 23 : 218-233, 1994.

ANGELOV D, CEYNOVA M, GUNTINAS-LICHIUS O, STREPPEL M, GROSHEVA M, KIRYAKOVA SI, SKOURAS E, MAEGELE M, IRINTCHEV A, NEISS W, SINIS N, ALVANOU A, DUNLOP SA: Mechanical stimulation of paralyzed vibrissal muscles following facial nerve injury in adult rat promotes full recovery of whisking. Neurobiol Dis 26: 229-242, 2007.

ARMSTEAD WM: Role of endothelin-1 in age-dependent cerebrovascular hypotensive responses after brain injury. $\mathrm{Am}$ J Physiol 277: H1884-H1894, 1999.

ARMSTEAD WM, KURTH CD: Different cerebral hemodynamic responses following fluid percussion brain injury in the newborn and juvenile pig. J Neurotrauma 11: 487-497, 1994.

BARNES CA: Memory deficits associated with senescence: A neurophysiological and behavioral study in the rat. J Comp Physiol Psychol 93: 74-104, 1979.

BELYAEV L, ALONSO OF, LIU Y, CHAPPELL AS, ZHAO W, GINSBERG MD, BUSTO R: Talampanel, a novel noncompetetive AMPA antagonist, is neuroprotective after traumatic brain injury in rats. J Neurotrauma $\mathbf{1 8}$ : 1031-1038, 2001.

BENAROYA-MILSHTEIN N: Environmental enrichment in mice decreases anxiety, attenuates stress responses and enhances natural killer cell activity. Eur J Neurosci 20: 1341-1347, 2004.

BENNETT EL, ROSENZWEIG MR, DIAMOND M: Rat brain: effects of environmental enrichment on wet and dry weights. Science 163: 825-826, 1969.

BENNETT JC, MCRAE PA, LEVY LJ, FRICK KM: Long-term continuous, but not daily, environmental enrichment reduces spatial memory decline in aged male mice. Neurobiol Learn Mem 85: 139-152, 2006.

BENTZER P, MATTIASSON G, MCINTOSH TK, WIELOCH T, GRANDE PO: Infusion of prostacyclin following experimental brain injury in the rat reduces cortical lesion volume. J Neurotrauma 18: 275-285, 2001.

BLINZINGER K, KREUTZBERG G: Displacement of synaptic terminals from regenerating motoneurons by microglial cells. Z Zellforsch Mikrosk Anat 85: 145-157, 1968.

BRAMLETT HM, DIETRICH WD: Chronic histopathological consequences of fluid-percussion brain injury in rats: effects of post-traumatic hypothermia. Acta Neuropathol (Berl) 93: 190-199, 1997. 
BROOK G, SCHMITT AB, NASCIMIENTO W, WEIS J, SCHRÖDER JM, NOTH J: Distribution of B-50 (GAP-43) mRNA and protein in the normal adult human spinal cord. Acta Neuropathol 95: 378-386, 1998.

BRUEL-JUNGERMAN E, LAROCHE S, RAMPON C: New neurons in the dentate gyrus are involved in the expression of enhanced long-term memory following environmental enrichment. Eur J Neurosci 21: 513-521, 2005.

BRUNS J, HAUSER WA: The epidemiology of traumatic brain injury: a review. Epilepsia 44 (Suppl 10): 2-10, 2003.

CHAPILLON P, MANNECHE C, BELZUNG C, CASTON J: Rearing environmental enrichment in two inbred strains of mice: 1. Effects on emotional reactivity. Behav Genet 29: 41-46, 1999.

CHEN X, LI Y, KLINE AE, DIXON CE, ZAFONTE RD, WAGNER AK: Gender and environmental effects on regional brain-derived neurotrophic factor expression after experimental traumatic brain injury. Neuroscience 135: 11-17, 2005.

CONNOR JR, WANG EC, DIAMOND MC: Increased length of terminal dendritic segments in old adult rats' somatosensory cortex: an environmentally induced response. Exp Neurol 78: 466-470, 1982.

CONTI AC, RAGUPATHI R, TROJANOWSKI JQ, MCINTOSH TK: Experimental brain injury induces regionally distinct apoptosis during the acute and delayed post-traumatic period. J Neurosci 18: 5663-5672, 1998.

CORTEZ SC, MCINTOSH TK: Experimental fluid percussion brain injury: vascular disruption and neuronal and glial alterations. Brain Res 482: 271-282, 1989.

DEBOW SB, DAVIES ML, CLARKE HL, COLBOURNE F: Constraint-induced movement therapy and rehabilitation exercises lessen motor deficits and volume of brain injury after striatal hemorrhagic stroke in rats. Stroke 34: 1021-1026, 2003.

DIAMOND MC, KRECH D: The effects of an enriched environment on the histology of the rat cerebral cortex. J Comp Neurol 123: 111-120, 1964.

DIAMOND MC, ROSENZWEIG MR, BENNETT EL, LINDNER B, LYON L: Effects of environmental enrichment and impoverishment on rat cerebral cortex. J Neurobiol 3: 47-64, 1972.

DIAMOND MC, INGHAM CA, JOHNSON RE, BENNETT EL, ROSENZWEIG MR: Effects of environment on morphology of rat cerebral cortex and hippocampus. J Neurobiol 7: 75-85, 1976.

DIETRICH WD, ALONSO O, BUSTO R, GLOBUS MY, GINSBERG MD: Post-traumatic brain hypothermia reduces histopathological damage following concussive brain injury in the rat. Acta Neuropathol 87: 250-258, 1994a.

DIETRICH WD, ALONSO O, HALLEY M: Early microvascular and neuronal consequences of traumatic brain injury: a light and electron microscopic study in rats. J Neurotrauma 11: 289-301, 1994b.

DIETRICH WD, ALONSO O, HALLEY M: Delayed posttraumatic brain hyperthermia worsens outcome after fluid percussion brain injury: a light and electron microscopic study in rats. Neurosurgery 38: 533-541, 1996.

DOBBING J: Undernutrition and the developing brain. In: Developmental Neurobiology. HIMWICH WA (ed), Thomas, Springfield, Illinois, 1970, pp 253-286.

DUNHAM NW, MIYA TS: A note on a simple apparatus for detecting neurological deficit in rats and mice. $J A m$ Pharmacol Assoc 46: 208-209, 1957.

EMERY DL, FULP CT, SAATMAN KE, FISCHER I, GRADY S, MCINTOSH TK: Bilateral growth-related protein expression suggests a transient increase in regenerative potential following brain trauma. J Comp Neurol 424: 521-531, 2000.

EMERY DL, RAGUPATHI R, SAATMAN KE, SCHUTZ C, NEUGEBAUER E, McINTOSH TK: Newly born granule cells in the dentate gyrus rapidly extend axons into the hippocampal CA3 region following experimental brain injury. J Neurotrauma 22: 978-988, 2005.

FADEN AI, O'LEARY DM, FAN L, BAO W, MULLINS PG, MOVSESYAN VA: Selective blockade of the mGluR1 receptor reduces traumatic neuronal injury in vitro and improves outcome after brain trauma. Exp Neurol 167: 435-444, 2001.

FADEN AI, KNOBLACH SM, CERNAK I, FAN L, VINK R, ARALDI GL, FRICKE ST, ROTH BL, KOZIKOWSKI AP: Novel diketopiperazine enhances motor and cognitive recovery after traumatic brain injury in rats and shows neuroprptection in vitro and in vivo. J Cerbr Blood Flow Metab 23: 342-354, 2003.

FAHERTY CJ, KERLEY D, SMEYNE R: A Golgi-Cox morphological analysis of neuronal changes induced by environmental enrichment. Brain Res Dev Brain Res 141: 55-61, 2003. 
FALKENBERG T, MOHAMMED AK: Increased expression of brain-derived neurotrophic factor mRNA in rat hippocampus is associated with improved spatial memory and enriched environment. Neurosci Lett 138: 153-156, 1992.

FOX GB, FAN L, LEVASSEUR RA, FADEN AI: Effect of traumatic brain injury on mouse spatial and nonspatial learning in the Barnes circular maze. J Neurotrauma 15: 1037-1046, 1998.

FRISKE JE, GAMMIE SC: Environmental enrichment alters plus maze, but not maternal defense performance in mice. Physiol Behav 85: 187-194, 2005.

FUKIDA K, TANNO H, OKIMURA Y, NAKAMURA M, YAMAURA A: The blood-brain barrier disruption to circulating proteins in the early period after fluid percussion brain injury in rats. J Neurotrauma 12: 315-325, 1995.

GAULKE LJ, HORNER PJ, FINK AJ, MCNAMARA CL, HICKS RR: Environmental enrichment increases progenitor cell survival in the dentate gyrus following lateral fluid percussion injury. Brain Res Mol Brain Res 141: 138-150, 2005.

GHAJAR J: Traumatic brain injury. Lancet 356: 923-929, 2000.

GRAHAM DI, RAGHUPATHI R, SAATMAN KE, MEANEY D, MCINTOSH TK: Tissue tears in the white matter after lateral fluid percussion brain injury in the rat: relevance to human brain injury. Acta Neuropathol (Berl) 99: 117-124, 2000.

GREENOUGH WT, VOLKMAR FR: Pattern of dendritic branching in occipital cortex of rats reared in complex environments. Exp Neurol 40: 491-504, 1973.

GREENOUGH WT, VOLKMAR FR, JURASKA JM: Effects of rearing complexity on dendritic branching in frontolateral and temporal cortex of the rat. Exp Neurol 41: 371-378, 1973.

GREENOUGH WT, HWANG HM, GORMAN C: Evidence for active synapse formation or altered postsynaptic metabolism in visual cortex of rats reared in complex environments. Proc Natl Acad Sci USA 82: 4549-4552, 1985.

GROW JL, LIU YG: Can lateralizing sensorimotor deficits be identified after neonatal cerebral hypoxia-ischemia in rats? Dev Neurosci 25: 394-402, 2003.

GUNDERSEN HJ: Stereology of arbitrary particles. A review of unbiased number and size estimators and the presentation of some new ones, in memory of William R. Thompson. J Microsc 143: 3-45, 1986.

GUNDERSEN HJ, JENSEN EB: The efficiency of systematic sampling in stereology and its prediction. J Microsc 147: 229-263, 1987.

GUNDERSEN HJ, BENDTSEN TF, KORBO L, MARCUSSEN N, MOLLER A, NIELSEN K, NYENGAARD JR, PAKKENBERG B, SORENSEN FB, VESTERBY A, WEST MJ: Some new, simple and efficient stereological methods and their use in pathological research and diagnosis. Acta Pathol Microbiol Immunol Scand 96: 379-394, 1988.

GUNTINAS-LICHIUS O, NEISS WF: Comparison of empirical and estimated efficiency in neuron counting by the physical dissector and in volume measurement by Cavalieri's method. Acta Stereol 15: 31-139, 1996.

GUNTINAS-LICHIUS O, NEISS WF, GUNKEL A, STENNERT E: Differences in glial, synaptic and motoneuron responses in the facial nucleus of the rat brainstem following facial nerve resection and nerve suture reanastomosis. Eur Arch Otorhinolaryngol 251: 410-417, 1994.

HAMM RJ, TEMPLE MD: Exposure to environmental complexity promotes recovery of cognitive function after traumatic brain injury. J Neurotrauma 13: 41-47, 1996.

HAMM RJ, PIKE BR, O'DELL DM, LYETH BG, JENKINS LW: The rotarod test: an evaluation of its effectiveness in assessing motor deficits following traumatic brain injury. J Neurotrauma 11: 187-196, 1994.

HEPP DO: The effects of early experience on problemsolving at maturity. Am Psychol 2: 306-307, 1947.

HICKS R, SOARES H: Temporal and spatial characterization of neuronal injury following lateral fluid-percussion brain injury in the rat. Acta Neuropathol (Berl) 91: 236-246, 1996.

HICKS RR, ZHANG L: Environmental enrichment attenuates cognitive deficits, but does not alter neurotrophin gene expression in the hippocampus following lateral fluid percussion brain injury. Neuroscience 112: 631-637, 2002. 
HICKS RR, KEELING KL, YANG MY, SMITH SA, SIMONS AM, KOTWAL GJ: Vaccinia virus complement control protein enhances functional recovery after traumatic brain injury. J Neurotrauma 19: 705-714, 2002.

HILL SJ, BARBARESE E: Regional heterogeneity in the response of astrocytes following traumatic brain injury in the adult rat. J Neuropathol Exp Neurol 55: 1221-1229, 1996.

HOFFMAN AN, MALENA RR: Environmental enrichment-mediated functional improvement after experimental traumatic brain injury is contingent on task-specific neurobehavioral experience. Neurosci Lett 431: 226-230, 2008.

ICKES BR, PHAM TM, SANDERS LA, ALBECK DS, MOHAMMED AH, GRANHOLM AC: Long-term environmental enrichment leads to regional increases in neurotrophin levels in rat brain. Exp Neurol 164: 45-52, 2000.

INGLIS FM, FIBIGER HC: Increases in hippocampal and frontal cortical acetylcholine release associated with presentation of sensory stimuli. Neuroscience 66: 81-86, 1995.

JOHNSON EM, TRAVER KL, HOFFMAN SW, HARRISON CR, HERMAN JP: Environmental enrichment protects against functional deficits caused by traumatic brain injury. Front Behav Neurosc 7: 44, 2013.

JONES BJ, ROBERTS DJ: A rotarod suitable for quantitative measurements of motor incoordination in naive mice. Naunyn Schmiedebergs Arch Exp Pathol Pharmakol 259: 211, 1968.

KEMPERMANN G, KUHN HG: More hippocampal neurons in adult mice living in an enriched environment. Nature 386: 493-495, 1997.

KEMPERMANN G, KUHN HG, GAGE FH: Experience-induced neurogenesis in the senescent dentate gyrus. J Neurosci 18: 3206-3212, 1998a.

KEMPERMANN G, BRANDON EP, GAGE FH: Environmental stimulation of 129/SvJ mice causes increased cell proliferation and neurogenesis in the adult dentate gyrus. Curr Biol 8: 939-942, 1998b.

KEMPERMANN G, GAST D, GAGE FH: Neuroplasticity in old age: sustained fivefold induction of hippocampal neurogenesis by long-term environmental enrichment. Ann Neurol 52: 135-143, 2002.

KNOBLACH SM, FADEN AI: Administration of either anti-intercellular adhesion molecule-1 or a nonspecific control antibody improves recovery after traumatic brain injury in the rat. J Neurotrauma 19: 1039-1050, 2002.

KOLB B, GIBB R: Environmental enrichment and cortical injury: behavioral and anatomical consequences of frontal cortex lesions. Cereb Cortex 1: 189-198, 1991.

KOVESDI E, GYORGY AB, KWON SK, WINGO DL, KAMNAKSH A, LONG JB, KASPER CE, AGOSTON DV: The effect of enriched environment on the outcome of traumatic brain injury; a behavioral, proteomics, and histological study. Front Neurosci 5: 42, 2011.

KOZLOWSKI DA, NAHED BV, HOVDA DA, LEE SM: Paradoxical effects of cortical impact injury on environmentally enriched rats. J Neurotrauma 21: 513-519, 2004.

LANGLOIS JA, RUTLAND-BROWN W: The epidemiology and impact of traumatic brain injury: a brief overview. J Head Trauma Rehabil 21: 375-378, 2006.

LAPLACA MC, ZHANG J, RAGHUPATHI R, LI JH, SMITH F, BAREYRE FM, SNYDER SH, GRAHAM DI, MCINTOSH TK: Pharmacologic inhibition of poly (ADP-ribose) polymerase is neuroprotective following traumatic brain injury in rats. $J$ Neurotrauma 18: 369-376, 2001.

LAURER HL, LENZLINGER PM: Models of traumatic brain injury. Eur J Trauma 26: 95-100, 2000.

LEE EH, HSU WL, MA YL, LEE PJ, CHAO CC: Enrichment enhances the expression of sgk, a glucocorticoid-induced gene, and facilitates spatial learning through glutamate AMPA receptor mediation. Eur J Neurosci 18: 2842$2852,2003$.

LEGGIO MG, MANDOLESI L, FEDERICO F, SPIRITO F, RICCI B, GELFO F, PETROSINI L: Environmental enrichment promotes improved spatial abilities and enhanced dendritic growth in the rat. Behav Brain Res 163: 78-90, 2005.

LIPPERT-GRUENER M, TERHAAG D: Multimodal early onset stimulation (MEOS) in rehabilitation after brain injury. Brain Inj 14: 585-594, 2000.

LIPPERT-GRUENER M, MAEGELE M: Late effects of enriched environment (EE) plus multimodal early onset stimulation (MEOS) after traumatic brain injury in rats: Ongoing improvement of neuromotor function despite sustained volume of the CNS lesion. Exp Neurol 203: 82-94, 2005. 
LIPPERT-GRUENER M, WEDEKIND C, ERNESTUS RI, KLUG N: Early rehabilitative concepts in therapy of the comatose brain injured patients. Acta Neurochir Suppl 79: 21-23, 2002.

LIPPERT-GRUENER M, WEDEKIND C, KLUG N: Outcome of prolonged coma following severe traumatic brain injury. Brain Inj 17: 49-54, 2003.

LIPPERT-GRUENER M, MAEGELE M, POKORNY J, ANGELOV D, SVESTKOVA O, WITTNER M, TROJAN S: Early rehabilitation model shows positive effects on neural degeneration and recovery from neuromotor deficits following traumatic brain injury. Physiol Res 56: 359-368, 2006 a.

LIPPERT-GRUENER M, MAEGELE M, ANGELOV D: Einfluss eines frühen sensomotorischen Trainings auf die Erholung neuromotorischer Defizite nach experimentellem Schädel-Hirn-Trauma. Phys Med Rehab Kuror 16: $1-6,2006 b$.

LONGHI L, SAATMAN KE, RAGHUPATHI R, LAURER HL, LENZLINGER PM, RIESS P, NEUGEBAUER E, TROJANOWSKI JQ, LEE VM, GRADY MS, GRAHAM DI, MCINTOSH TK: A review and rationale for the use of genetically engineered animals in the study of traumatic brain injury. J Cereb Blood Flow Metab 21: 1241-1258, 2001.

LOZADA A, MAEGELE M, STARK H, NEUGEBAUER EM, PANULA P: Traumatic brain injury results in mast cell increase and changes in regulation of central histamine receptors. Neuropathol Appl Neurobiol 31: 150-162, 2005.

MAEGELE M, LIPPERT-GRUENER M: Multimodal early onset stimulation combined with enriched environment is associated with reduced CNS lesion volume and enhanced reversal of neuromotor dysfunction after traumatic brain injury in rats. Eur J Neurosci 21: 2406-2418, 2005a.

MAEGELE M, LIPPERT-GRUENER M: Reversal of neuromotor and cognitive dysfunction in an enriched environment combined with multimodal early onset stimulation after traumatic brain injury in rats. J Neurotrauma 22: 772-782, 2005b.

MAEGELE M, ESTER-BODE T, RIESS P, ANGELOV DN, MCINTOSH TK, NEUGEBAUER E, LIPPERTGRUENER M: Exposure to complex enriched environment combined with multi-modal stimulation promotes recovery of cognitive function after traumatic brain injury in rats. Lang Arch Sur 387: 266, 2002.

MAEGELE M, RIESS P, SAUERLAND S, BOUILLON B, HESS S, MCINTOSH TK, MAUTES A, BROCKMANN M, KOEBKE J, KNIFKA J, NEUGEBAUER EA: Characterization of a new rat model of experimental combined neurotrauma. Shock 23: 476-481, 2005.

MAEGELE M, ENGEL D, BOUILLON B, LEFERING R, FACH H, RAUM M, BUCHHEISTER B, KLUG N, NEUGEBAUER E: The incidence and outcome of traumatic brain injury in an urban area in western Europe over ten years. Eur Surg Res 39: 372-379, 2007 a.

MAEGELE M, SAUERLAND S, BOUILLON B, SCHAEFER U, NEUGEBAUER E: Immunmodulation in a new „two-hit“-model of experimental combined neurotrauma. Inflamm Res 56: 318-323, $2007 \mathrm{~b}$.

MARANGOS PJ, SCHMECHEL DE: Neuron specific enolase, a clinically useful marker for neurons and neuroendocrine cells. Annu Rev Neurosci 10: 269-295, 1987.

MARKLUND N, CLAUSEN F, MCINTOSH TK, HILLERED L: Free redical scavenger posttreatment improves functional and morphological outcome after fluid percussion injury in the rat. J Neurotrauma 18: 821-832, 2001.

MATTER AM, FOLWEILER KA, CURATOLO LM, KLINE AE: Temporal effects of environmental enrichmentmediated functional improvement after experimental traumatic brain injury in rats. Neurorehabil Neural Repair 25: 558-564, 2011.

MAYHEW TM: The new stereological methods for interpretating functional morphology from slices of cells and organs. Exp Physiol 76: 639-665, 1991.

MCINTOSH TK, VINK R: Traumatic brain injury in the rat: characterization of a lateral fluid-percussion model. Neuroscience 28: 233-244, 1989.

MOLCANYI M, RIESS P, BENTZ K, MAEGELE M, HESCHELER J, SCHAFKE B, TRAPP T, NEUGEBAUER E, KLUG N, SCHAEFER U: Trauma-associated inflammatory response impairs embryonic stem cell survival and integration after implantation into injured brain. J Neurotrauma 24: 625-637, 2007. 
MORALES DM, MARKLUND N, LEBOLD D, THOMPSON HJ, PITKANEN A, MAXWELL WL, LONGHI L, LAURER H, MAEGELE M, NEUGEBAUER E, GRAHAM DI, STOCCHETTI N, MCINTOSH TK: Experimental models of traumatic brain injury: do we really need to build a better mousetrap? Neuroscience 136: 971-989, 2005.

MOSER MB, TROMMALD M, EGELAND T, ANDERSEN P: Spatial training in a complex environment and isolation alter the spine distribution differently in rat CA1 pyramidal cells. J Comp Neurol 380: 373-381, 1997.

MURRAY CJL, LOPEZ AD: Global mortality, disability and the contribution of risk factors: Global Burden of Disease Study. Lancet 349: 1436-1442, 1997.

MYSLIVECEK J, HASSMANNOVA J: Some neurophysiological mechanisms of early inhibitory learning and memory. In: Ontogenesis of the Brain. TROJAN S, ŠŤASTNÝ F (eds), Charles University, Prague, 1987, pp 117-122.

NAVONE F, JAHN R, DI GIOIA G, STUKENBROK H, GREENGARD P, DE CAMILLI P: Protein p38: an integral membrane protein specific for small vesicles of neurons and neuroendocrine cells. J Cell Biol 103: 2511-2527, 1986.

NEISS WF, GUNTINAS-LICHIUS O, ANGELOV DN, GUNKEL A, STENNERT E: The hypoglossal-facial anastomosis as model of neuronal plasticity in the rat. Ann Anat 174: 419-433, 1992.

NILSSON M, PERFILIEVA E: Enriched environment increases neurogenesis in the adult rat dentate gyrus and improves spatial memory. J Neurobiol 39: 569-578, 1999.

NITHIANANTHARAJAH J, HANNAN AJ: Enriched environments, experience-dependent plasticity and disorders of the nervous system. Nature Rev Neurosci 7: 697-709, 2006.

OKIYAMA K, SMITH DH, THOMAS MJ, MCINTOSH TK: Evaluation of a novel calcium channel blocker, (S)-emopamil, on regional cerebral edema and neurobehavioral function after experimental brain injury. J Neurosurg 77: 607-615, 1992.

PASSINEAU MJ, GREEN EJ: Therapeutic effects of environmental enrichment on cognitive function and tissue integrity following severe traumatic brain injury in rats. Exp Neurol 168: 373-384, 2001.

PERUZZARO ST, GALLAGHER J, DUNKERSON J, FLUHARTY S, MUDD D, HOANE MR, SMITH JS: The impact of enriched environment and transplantation of murine cortical embryonic stem cells on recovery from controlled cortical contusion injury. Restor Neurol Neurosci 31: 431-450, 2013.

PHAM TM, ICKES B, ALBECK D, SÖDERSTRÖM S, GRANHOLM AC, MOHAMMED AH: Changes in brain nerve growth factor levels and nerve growth factor receptors in rats exposed to environmental enrichment for one year. Neuroscience 94: 279-286, 1999.

PHILIPS MF, MATTIASSON G, WIELOCH T, BJORKLUND A, JOHANSSON BB, TOMASEVIC G, MARTINEZSERRANO A, LENZLINGER PM, SINSON G, GRADY MS, MCINTOSH TK: Neuroprotective and behavioral effects of nerve growth factor-transfected hippocampal progenitor cell transplants after experimental traumatic brain injury. J Neurosurg 94: 765-774, 2001.

PIERCE JE, TROJANOWSKI JQ: Immunohistochemical characterization of alterations in the distribution of amyloid precursor proteins and beta-amyloid peptide after experimental brain injury in the rat. $J$ Neurosci 16: 10831090, 1996.

PIERCE JE, SMITH DH: Enduring cognitive, neurobehavioral and histopathological changes persist for up to one year following severe experimental brain injury in rats. Neuroscience 87: 359-369, 1998.

POVLISHOCK JT, ERB DE: Axonal response to traumatic brain injury: reactive axonal change, deafferentation, and neuroplasticity. J Neurotrauma 9 (Suppl 1): S189-S200, 1992.

RAMPON C, TANG YP, GOODHOUSE J, SHIMIZU E, KYIN M, TSIEN JZ: Enrichment induces structural changes and recovery from nonspatial memory deficits in CA1 NMDAR1-knockout mice. Nat Neurosci 3: 238-244, 2000a.

RAMPON C, JIANG CH, DONG H, TANG YP, LOCKHART DJ, SCHULTZ PG, TSIEN JZ, HU Y: Effects of environmental enrichment on gene expression in the brain. Proc Natl Acad Sci USA 97: 12880-12884, $2000 \mathrm{~b}$.

RICE AC, ZSOLDOS R, CHEN T, WILSON MS, ALESSANDRI B, HAMM RJ, BULLOCK MR: Lactate administration attenuates cognitive deficits following traumatic brain injury. Brain Res 928: 56-59, 2002. 
RIESS P, BAREYRE FM, SAATMAN KE, CHENEY JA, LIFSHITZ J, RAGHUPATHI R, GRADY MS, NEUGEBAUER E, MCINTOSH TK: Effects of chronic, post-injury Cyclosporin A administration on motor and sensorimotor function following severe, experimental traumatic brain injury. Restor Neurol Neurosci 18: $1-8,2001$.

RIESS P, ZHANG C, SAATMAN KE, LAURER HL, LONGHI LG, RAGHUPATHI R, LENZLINGER PM, LIFSHITZ J, BOOCKVAR J, NEUGEBAUER E, SNYDER EY, MCINTOSH TK: Transplanted neural stem cells survive, differentiate, and improve neurological motor function after experimental traumatic brain injury. Neurosurgery 51: 1043-1052, 2002.

RIESS P, MOLCIANY M, BENTZ C, MAEGELE M, SIMANSKI C, CARLITESCHECK C, BOUILLON B, HESCHELER J, SCHNEIDER A, SCHÄFER U, NEUGEBAUER E: Embryonic stem cell transplantation after experimental traumatic brain injury dramatically improves neurological outcome, but may cause tumors. J Neurotrauma 24: 216-225, 2007.

RINK A, FUNG K-M, TROJANOWSKI JQ, LEE V, NEUGEBAUER E, MCINTOSH T: Evidence of apoptotic cell death after experimental traumatic brain injury in the rat. Am J Pathol 147: 1575-1583, 1995.

ROSENZWEIG MR: Environmental complexity, cerebral change, and behavior. Am Psychol 21: 321-332, 1966.

ROY V, BELZUNG C, DELARUE C, CHAPILLON P: Environmental enrichment in BALB/c mice: effects in classical tests of anxiety and exposure to a predatory odor. Physiol Behav 74: 313-320, 2001.

SAATMAN KE, BAREYRE FM, GRANDY MS, MCINTOSH TK: Acute cytoskeletal alterations and cell death induced by experimental brain injury are attenuated by magnesium treatment and exacerbated by magnesium deficiency. J Neuropathol Exp Neurol 60: 183-194, 2001.

SCHALLERT T, FLEMING SM: CNS plasticity and assessment of forelimb sensorimotor outcome in unilateral rat models of stroke, cortical ablation, parkinsonism and spinal cord injury. Neuropharmacology 39: 777-787, 2000.

SCHERBEL U, RAGHUPATHI R, NAKAMURA M, SAATMAN KE, TROJANOWSKI JQ, NEUGEBAUER E, MARINO M, MCINTOSH T: Differential acute and chronic responses of tumor necrosis factor-deficient mice to experimental brain injury. Proc Natl Acad Sci USA 96: 8721-8726, 1999.

SCHMIDT RH, GRADY MS: Regional patterns of blood-brain barrier breakdown following central and lateral fluid percussion injury in rodents. J Neurotrauma 10: 415-429, 1993.

SCHRIJVER NC, BAHR NI, WEISS IC, WURBEL H: Dissociable effects of isolation rearing and environmental enrichment on exploration, spatial learning and HPA activity in adult rats. Pharmacol Biochem Behav 73: 209-224, 2002.

SCHUTZ C, STOVER JF, THOMPSON HJ, HOOVER RC, MORALES DM, SCHOUTEN JW, MCMILLAN A, SOLTESZ K, MOTTA M, SPANGLER Z, NEUGEBAUER E, MCINTOSH TK: Acute, transient hemorrhagic hypotension does not aggravate structural damage or neurologic motor deficits but delays the long-term cognitive recovery following mild to moderate traumatic brain injury. Crit Care Med 34: 492-501, 2006.

SCHWARTZ S: Effect of neonatal cortical lesions and early environmental factors on adult rat behavior. $J$ Comp Physiol Psychol 57: 72-77, 1964.

SINSON G, VODDI M, MCINTOSH TK: Nerve growth factor administration attenuates cognitive but not neurobehavioral motor dysfunction or hippocampal cell loss following fluid-percussion brain injury in rats. J Neurochem 65: 2209-2216, 1995.

SMITH DH, CHEN XH: Progressive atrophy and neuron death for one year following brain trauma in the rat. J Neurotrauma 14: 715-727, 1997.

SOARES HD, HICKS RR, SMITH D, MCINTOSH TK: Development of prolonged focal cerebral edema and regional cation changes following experimental brain injury in the rat. J Neurochem 58: 1845-1852, 1992.

SOARES HD, HICKS RR, SMITH D, MCINTOSH TK: Inflammatory leukocytic recruitment and diffuse neuronal degeneration are separate pathological processes resulting from traumatic brain injury. $J$ Neurosci 15: 8223$8233,1995$.

SOSIN DM, SNIEZEK JE, THURMAN DJ: Incidence of mild and moderate brain injury in the United States. Brain Inj 10: 47-54, 1991. 
SOZDA CN, HOFFMAN AN, OLSEN AS, CHENG JP, ZAFONTE RD, KLINE AE: Empirical comparison of typical and atypical environmental enrichment paradigms on functional and histological outcome after experimental traumatic brain injury. $J$ Neurotrauma 27: 1047-1057, 2010.

STEIN SC, CHEN XH, SINSON GP, SMITH DH: Intravascular coagulation: a major secondary insult in nonfatal traumatic brain injury. J Neurosurg 97: 1373-1377, 2002.

SULLIVAN HG, MARTINEZ J, BECKER DP, MILLER JD, GRIFFITH R, WIST A: Fluid-percussion model of mechanical brain injury in the cat. $J$ Neurosurg 45: 521-534, 1976.

TANG YP, WANG H, FENG R, KYIN M, TSIEN JZ: Differential effects of enrichment on learning and memory function in NR2B transgenic mice. Neuropharmacology 41: 779-790, 2001.

TORASDOTTER M, METSIS M, HENRIKSSON BG, WINBLAD B, MOHAMMED AH: Environmental enrichment results in higher levels of nerve growth factor mRNA in the rat visual cortex and hippocampus. Behav Brain Res 93: 83-90, 1998.

TURNER AM, GREENOUGH WT: Differential rearing effects on rat visual cortex synapses. I. Synaptic and neuronal density and synapses per neuron. Brain Res 329: 195-203, 1985.

VAN PRAAG H, KEMPERMANN G, GAGE FH: Neural consequences of environmental enrichment. Nature Rev Neurosci 1: 191-198, 2000.

VAN RIJZINGEN IM, GISPEN WH, SPRUIJT BM: Postoperative environmental enrichment attenuates fimbria-fornix lesion-induced impairments in Morris maze performance. Neurobiol Learn Mem 67: 21-28, 1997.

WAGNER AK, KLINE AE, SOKOLOSKI J, ZAFONTE RD, CAPULONG E, DIXON CE: Intervention with environmental enrichment after experimental brain trauma enhances cognitive recovery in male but not female rats. Neurosci Lett 334: 165-168, 2002.

WAGNER AK, CHEN X, KLINE AE, LI Y, ZAFONTE RD, DIXON CE: Gender and environmental enrichment impact dopamine transporter expression after experimental traumatic brain injury. Exp Neurol 195: 475-483, 2005.

WAHL F, GROSJEAN-PIOT O, BAREYRE F, UZAN A, STUTZMANN JM: Enoxaparin reduces brain edema, cerebral lesions, and improves motor and cognitive impairments induced by a traumatic brain injury in rats. J Neurotrauma 17: 1055-1065, 2000.

WAXWEILER RJ, THURMAN D: Monitoring the impact of traumatic brain injury: a review and update. J Neurotrauma 12: 509-516, 1995.

WEST MJ, GUNDERSEN HJ: Unbiased stereological estimation of the number of neurons in the human hippocampus. J Comp Neurol 296: 1-22, 1990.

WHISHAW IQ, ZABOROWSKI JA, KOLB B: Postsurgical enrichment aids adult hemidecorticate rats on a spatial navigation task. Behav Neural Biol 42: 183-190, 1984.

WIEDENMANN B, FRANKE WW: Identification and localization of synaptophysin, an integral membrane glycoprotein of Mr 38,000 characteristic of presynaptic vesicles. Cell 41: 1017-1028, 1985.

WILL BE, ROSENZWEIG MR, BENNETT EL: Effects of differential environments on recovery from neonatal brain lesions, measured by problem-solving scores and brain dimensions. Physiol Behav 16: 603-611, 1976. 